\title{
Historical perspectives of The American Association for Thoracic Surgery: John L. Ochsner, MD (1927-)
}

\author{
Jeffrey M. Griffin, MD, and John S. Ikonomidis, MD, PhD
}

John Lockwood Ochsner (Figure 1), the 73rd president of The American Association of Thoracic Surgery (AATS), was born on February 10, 1927, in Madison, Wisconsin. $\mathrm{He}$ is the son of Dr Alton Ochsner, 27th president of the AATS, and is also a descendent of Dr Albert J. Ochsner, founder and first president of the American College of Surgeons. When he was 3 months old, Ochsner's family moved to New Orleans after his father was appointed chairman of surgery at Tulane. Ochsner described his father as a taskmaster and somewhat distant during his childhood years; however, they would ultimately grow very close personally and professionally. Both men would become renowned surgeons and educators, serve prominently at the Ochsner Clinic in New Orleans, and be considered heroes of southern medicine. Michael DeBakey figured into the Ochsner legacy in a most important way-Alton Ochsner served as an early mentor to DeBakey, who in turn served as an early mentor to John Ochsner. John Ochsner described early his memories of DeBakey, "I knew him as Mike, because he was our babysitter . . . when I was a kid." " "[I]n fact he spent his honeymoon at our house. Mother and dad went to Europe on a trip and Dr DeBakey was getting married . . . and dad . . . said why don't you all just stay at . . our house, and ya'll can take care of the children, so they did. His wife, Dianna, stayed with us and I remember them babysitting at other times for us. He was a great babysitter, and of course at that time, he was Mike to me, you know. Not Dr DeBakey, but it was a different situation. He was very, very devoted to my father. He had four sons, and the middle name, each one had a middle name that was Ochsner ... they were very, very close. My mother was very close with Dr DeBakey. She felt like he was a son."2

\section{EDUCATION AND SURGICAL TRAINING}

Ochsner attended Darlington School in Rome, Georgia, where excelled in academics and lettered in 5 sports: football, basketball, baseball, tennis, and javelin. He then

\footnotetext{
From the Division of Cardiothoracic Surgery, Medical University of South Carolina, Charleston, SC.

Disclosures: Authors have nothing to disclose with regard to commercial support.

Received for publication Feb 20, 2014; accepted for publication Feb 21, 2014; available ahead of print March 20, 2014.

Address for reprints: John S. Ikonomidis, MD, PhD, Horace G. Smithy Professor, Chief, Division of Cardiothoracic Surgery, Medical University of South Carolina, 25 Courtenay Dr, Suite 7030, Charleston, SC 29425 (E-mail: ikonomij@musc. edu).

J Thorac Cardiovasc Surg 2014;147:1735-7

$0022-5223 / \$ 36.00$

Copyright (c) 2014 by The American Association for Thoracic Surgery

http://dx.doi.org/10.1016/j.jtcvs.2014.02.065
}

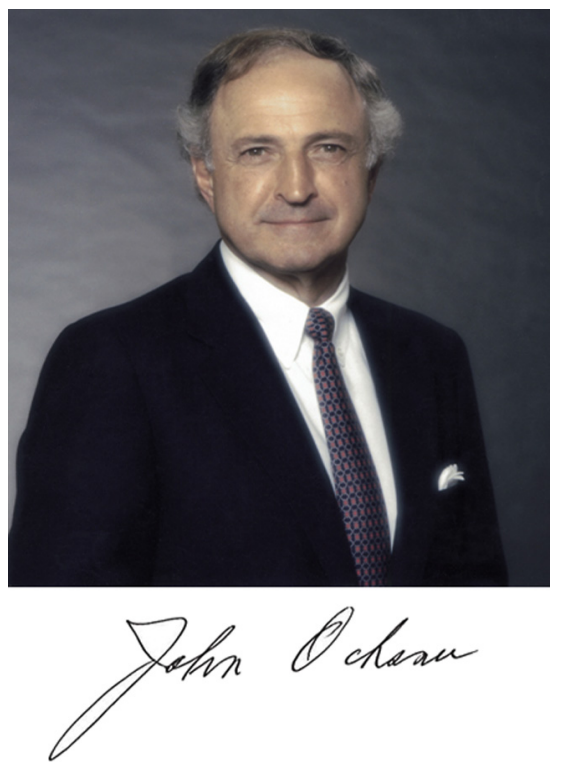

FIGURE 1. John Lockwood Ochsner, MD.

attended Tulane for college and medical school. Ochsner began his surgical residency in 1952 at the University of Michigan under Dr Frederick Coller, before being drafted into military service during the Korean War. After this service, he completed his surgical residency in Houston under Michael DeBakey. Despite his close family ties to DeBakey, it is evident that Ochsner was not expecting any special treatment from his former babysitter, "Mike." He knew the man his father had trained would throw him right into the trenches. Ochsner described his time with DeBakey as tough but rewarding. He was in Houston from 1956 to 1961, a time he described as "the beginning of heart surgery," ${ }^{3}$ and even received permission from DeBakey to spend a year working at Texas Children's Hospital with Dr Denton Cooley. During Ochsner's time in Houston, he trained under, and became lifelong friends with, both of these giants in the field of cardiothoracic surgery.

\section{SURGICAL CAREER}

Ochsner stayed briefly in Houston as an instructor at Baylor University after completing his training. Despite an invitation to stay at Baylor with DeBakey, Ochsner and his wife, Mary Lou, returned home in 1961. He recounted this decision: " $[\mathrm{M}]$ y last name was on a clinic in New Orleans. Patients were coming from the Ochsner Clinic to Houston for their heart surgery or vascular surgery, because it wasn't 


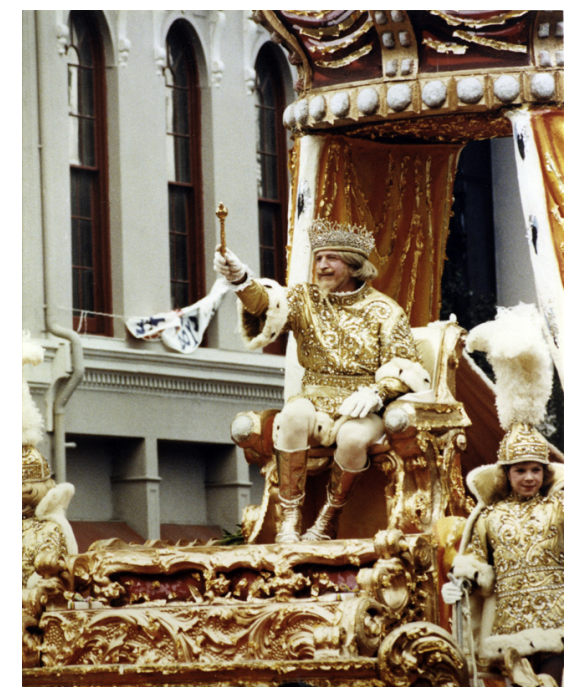

FIGURE 2. "Pro Bono Publico-for the public good." Ochsner as Rex, King of Carnival, greets the public from atop his float during the 1990 Mardi Gras Parade in New Orleans.

going very well in New Orleans. It was almost embarrassing to me, and I wanted to go back .... I remember walking into the doctors' lounge at the Ochsner Clinic and overhearing an anesthesiologist say, 'If he thinks they're going to start heart surgery here again, he's nuts." ${ }^{3}$ With internal dissent within the institution, Birmingham to the south, and Houston to the west, he faced a daunting challenge. He persevered though these challenges, and the rapidly changing landscape of cardiac surgery in the 1960s and 1970s, ultimately turning the clinic bearing his name into a major cardiac surgery center. He described his early experience with the Kay-Cross oxygenator as "a mess." On one occasion, the oxygenator's rotating disk mechanism malfunctioned, and his father, who happened to be passing by the operating room, came in and manually turned the disk for the remainder of the case. Experiences with the bubble oxygenator led to an important early contribution to the literature on the causes, prevention, and management of air embolism during cardiopulmonary bypass. ${ }^{4}$ Ochsner performed many firsts in his community, including early experience with valve and coronary surgery, pacemakers, and first heart, lung, and liver transplants. His career spanned several decades, during which he participated in the evolution of myocardial revascularization, including performing hundreds of Vineberg operations. He also made important contributions to the literature, reporting his extensive early experience with bypass grafts including cryopreserved and autologous saphenous vein grafts as well as the internal thoracic artery. ${ }^{5-7}$

\section{CURRICULUM VITAE HIGHLIGHTS}

Ochsner has authored more than 300 peer-reviewed publications. He has served on numerous professional boards and committees. Of note, he is the only person to serve as president of the AATS (1992-1993), chair of the American Board of Thoracic Surgery (1993-1995), and president of the International Society for Cardiovascular

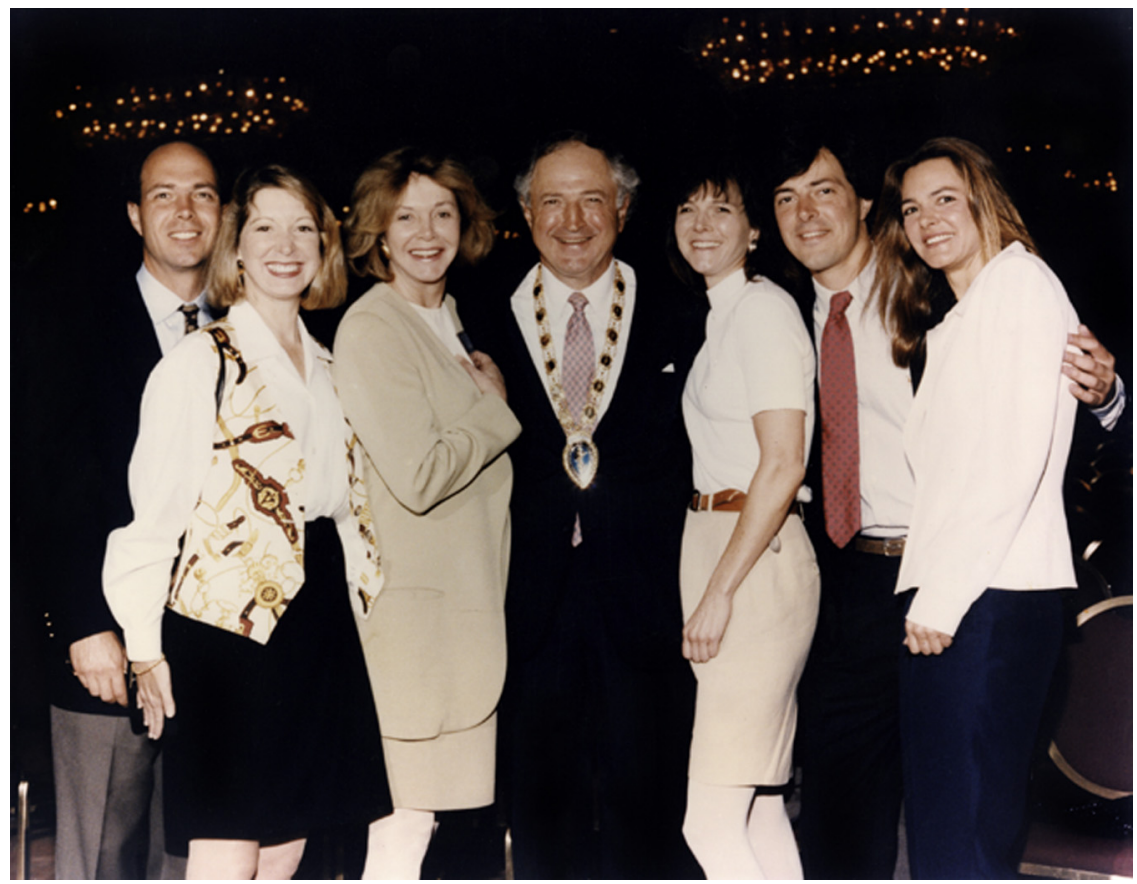

FIGURE 3. Dr John L. Ochsner with his family. From left: Dr Lock Ochsner, Lori Ochsner, Mary Lou Ochsner, Dr J. L. Ochsner, Dr Katherine Ochsner, Frank Ochsner, and Joby Ochsner. 
Surgery. He is the recipient of many awards and honors. Perhaps the most unusual honor bestowed on Ochsner has been that of Rex, King of Carnival, in 1990 (Figure 2). In New Orleans, this is considered among the highest civic honors one may receive. It is notable that his father also served as Rex in 1948. It is thought that they are the only 2 people not native to New Orleans to receive this honor.

\section{SUMMARY OF AATS PRESIDENTIAL ADDRESS}

Dr Ochsner's presidential address, "Giants," was delivered in 1993 at the 73rd annual meeting of the AATS in Chicago. ${ }^{8}$ This address detailed the development of surgical education and professional organizations during the 1900s and described the evolving measures of performance and success within academic hospitals. He discussed how this progress changed the definition of what it means to be a surgical giant and also changed the style of thoracic surgical training. He reflected on his address, saying that he never considered himself a surgical giant. He maintains that during his career he trained a group of residents to have technical and clinical abilities as good as his own.

\section{PERSONAL LIFE}

Ochsner has been married to his wife, Mary Lou, for more than 50 years. Both Ochsner and his father Alton had long, successful marriages that began during their surgical training. A. J. Ochsner, founder of the American College of Surgeons and mentor to Alton Ochsner, believed that no surgeons should marry until their goals were achieved and they had attained the rank of full professor. John Lockwood Ochsner's mother often lamented that A. J. did not survive long enough to see Alton Ochsner reach his goal. She would be proud to know that John Lockwood Ochsner also reached his goal, and that he attributes his success to Mary Lou's dedication and patience. Together they have 4 children (Figure 3). Since his retirement, Ochsner enjoys playing golf. He is a voracious reader, especially of history. He remains active in many civic organizations and has an ongoing role in the promotion of the Ochsner Clinic.

\section{References}

1. Ikonomidis J. Unpublished personal interview with JL Ochsner. Conducted at the 91st American Association for Thoracic Surgery Meeting. 2011 May 9; Philadelphia.

2. Interview with JL Ochsner [audiotape]. Conducted at the 91st Annual Meeting of The American Association for Thoracic Surgery; May 9, 2011; Philadelphia, Pa.

3. Stoney WS. John L. Ochsner, MD. In: Pioneers of cardiac surgery. Nashville, TN: Vanderbilt University Press; 2008:391-404.

4. Mills NL, Ochsner JL. Massive air embolism during cardiopulmonary bypass Causes, prevention, and management. J Thorac Cardiovasc Surg. 1980;80: 708-17.

5. Ochsner JL, Moseley PW, Mills NL, Bower PJ. Long-term follow-up of internal mammary artery myocardial implantation. Ann Thorac Surg. 1977;23: $118-21$.

6. Mills NL, Ochsner JL. Technique of internal mammary-to-coronary artery bypass Ann Thorac Surg. 1974; 17:237-46.

7. Ochsner JL, Lawson JD, Eskind SJ, Mills NL, DeCamp PT. Homologous veins as an arterial substitute: long-term results. J Vasc Surg. 1984;1:306-13.

8. Ochsner JL. Giants. J Thorac Cardiovasc Surg. 1993;106:769-78. 